\title{
NAZARIYYAT
}

\section{Was Qutb al-Din al-Razi al-Tahtani a Sunni or a Shi'i?: An Examination of Bio-bibliographical Sources*}

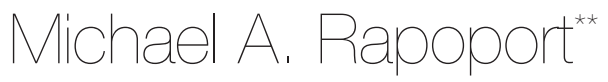

\begin{abstract}
Quṭb al-Dīn al-Rāzĩ al-Tahhtānī (d. 766/1365) was one of a triumvirate of scholars allegedly associated with Shī'ism - the other two being al-Allāma al-Hillì (d. 726/1325) and Badr al-Dīn al-Tustarī (d. 732/1332) - who played an important role in shaping and transmitting Avicennan thought. Through their adjudicative commentaries on Ibn Sīnā's (d. 428/1037) al-Ishārāt wa-l-tanbỉhāt, al-Taḥtānì, al-Ḥillì, and al-Tustarī created a narrative that pitted Sunnī scholars critical of Ibn Sīnā and Avicennism - exemplified by Fakhr al-Dīn al-Rāzì (d. 606/1210) - in opposition to their Twelver Shîî defenders and interpreters exemplified by Nașîr al-Dīn al-Ṭūsī (d. 672/1274). This understanding of post-Avicennan Arabic and Islamic philosophy is informed by the assumption that these three scholars were all, in fact, Shìis. Many biobibliographical sources, however, claim that al-Tahtāni was not. This article examines the sources for his life, paying particular attention to the question of his sectarian affiliation. It reveals that Sunni and Shîi scholars relied on different sources for and relayed different information about al-Tahtānī's life. Ultimately, it claims that the evidence suggests that he was a Sunni.
\end{abstract}

Keywords: Quṭb al-Dīn al-Rāzì al-Taḥtānī, Philosophy, Postclassical Era, Avicennism, Biographical Dictionaries

\footnotetext{
* I would like to thank Ahmed al-Rahim and the two anonymous reviewers for their helpful comments on this paper. All of the shortcomings and limitations that remain are mine.

** Assistant Professor, Department of Languages, Linguistics, and Comparative Literature, Florida Atlantic University, Correspondence: mrapoport@fau.edu.
} 


\section{Introduction}

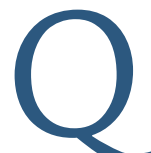

uṭb al-Dīn al-Rāzī al-Taḥtānī (d. 766/1365) was best known for his commentary on al-Kātibī's (d. 675/1277) al-Risāla al-Shamsiyya ${ }^{1}$ and his adjudicative supercommentary (muḥākama) on Ibn Sīnā's (d. 428/1037) al-Ishärät wa-l-tanbīhăt. ${ }^{2}$ In fact, due to this latter work, he came to play a prominent role in transmitting Avicennan thought and in creating a narrative of Arabic philosophy and theology in the post-Avicennan era. It is perhaps more accurate to say, however, that al-Tahtānī was an important transmitter of Avicennan thought as interpreted by Nașir al-Dīn al-Ṭūsī (d. 672/1274). He was not alone in this endeavor, but was one of a triumvirate of scholars - the other two being al-'Allāma al-Hillì (d. 726/1325) and Badr al-Dīn al-Tustarī (d. 732/1332) - all of whom wrote adjudicative commentaries on Ibn Sīnā's al-Ishärät, purporting to judge fairly between its two most prominent and influential commentators - the Sunnī Ash'arī Fakhr al-Dīn al-Rāzī (d. 606/1210) and the Twelver Shīî̀ Nașīr al-Dīn al-Ṭūsī. ${ }^{3}$

This is not all that they have in common. They all purportedly were, along with al-Ṭūsī, adherents of Twelver Shī'ism. Furthermore, al-Ḥillī was a student of al-Ṭūsī, al-Taḥtānī was a student of al-Hịllīi, ${ }^{4}$ and al-Hịllī and al-Tustarī were colleagues. ${ }^{5}$ Together, they created a narrative that pitted Sunni theologians, most especially Fakhr al-Dīn al-Rāzī, as foolish critics of Ibn Sīnā, in opposition to his Twelver Shîî̀ defenders and interpreters, most especially al-Ṭūsī. As Wisnovsky noted recently, this narrative was adopted by Safavi-era Twelver scholars and continues to dominate Iranian historiography of Islamic philosophy. ${ }^{6}$

1 On this, see Tony Street, "Kātibī (d. 1277), al-Taḥtānī (d. 1365), and the Shamsiyya," in The Oxford Handbook of Islamic Philosophy, ed. Khaled El-Rouayheb and Sabine Schmidtke (New York: Oxford University Press, 2016), 348-74.

2 For al-Taḥtānī's bibliography, see Ahmed H. al-Rahim, The Creation of Philosophical Tradition: Biography and the Reception of Avicenna's Philosophy from the Eleventh to the Fourteenth Century A.D. (Wiesbaden: Harrassowitz, 2018), 138-43.

3 On the al-Ishārāt's commentary tradition, see Robert Wisnovsky, "Avicennism and Exegetical Practice in the Early Commentaries on the al-Ishārāt," Oriens 41, no. 3-4 (2013): 349-78.

4 Sabine Schmidtke, "Helli, Hasan b. Yusof b. Moțahhar," in Encyclopaedia Iranica, 2012, http://www. iranicaonline.org/articles/helli-hasan-b-yusof-b-motahhar; Gerhard Endress, "Reading Avicenna in the Madrasa: Intellectual Genealogies and Chains of Transmission of Philosophy and the Sciences in the Islamic East," in Arabic Theology, Arabic Philosophy. From the Many to the One: Essays in Celebration of Richard M. Frank, ed. James E. Montgomery (Leuven: Peeters, 2006), 420; Robert Wisnovsky, "Towards a Genealogy of Avicennism," Oriens 42, no. 3-4 (2014): 358; Street, “Kātibī (d. 1277),” 268.

5 Wisnovsky, "Genealogy," 358.

6 Robert Wisnovsky, "On the Emergence of Maragha Avicennism," Oriens 46, no. 3-4 (2018): 264, 304. This narrative also bears a resemblance to the traditional telling of the history of Arabic/Islamic philosophy and theology, first developed in nineteenth-century Europe and widely adopted by 
This reading of these three scholars' roles in promoting a particular telling of post-Avicennan Arabic/Islamic philosophy and theology rests on the understanding that each one was, in fact, a Twelver Shī'î. Wisnovsky acknowledges that al-Tustari

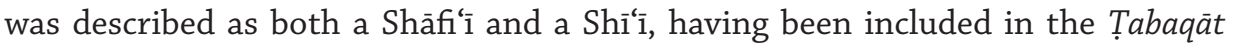
al-Shāfìyya composed by his student 'Abd al-Raḥmān al-Asnawī (or al-Isnawī, d. 772/1370), ${ }^{7}$ but maintains that he was Shī'ì. Al-Asnawī similarly included al-Taḥtānī in his Țabaqāt. Though al-Asnawī explicitly refers to al-Tustarī as a Shī'î, calling him a rāfị̂̀i, he makes no explicit statement as to al-Taḥtānī's sectarian affiliation. ${ }^{8}$ Ahmed al-Rahim has recently argued that al-Taḥtānī was actually a Sunnī. ${ }^{9}$ If this is correct, then we must reassess how we understand his role alongside al-Hillī and al-Tustarī in transmitting and transforming Avicennism in the post-classical era of Arabic and Islamic scholarship (ca. 1200-1900).

This article examines al-Taḥtānī's sectarian affiliation based on biobibliographical sources. There are abundant sources for al-Tahtānī's life. Among modern biographical notices, Kaḥhāla's entry on him in Mu'jam al-mu'allifin and the notice on al-Taḥtānī in the Mawsū'at țabaqāt al-fuqahā' both list twenty-one sources, whereas Ziriklī's entry on him in his A'ām has eleven. ${ }^{10}$ For this study, I examined as many of the sources mentioned therein as were accessible. In sum, these amounted to twenty-six sources from the eighth/fourteenth to thirteenth/ nineteenth centuries. ${ }^{11}$

There are certain patterns in the bio-bibliographical sources on al-Tahtānī. The main one is that Sunnī and Shī'î scholars often relied on different sources

European and North American scholars until roughly the turn of the twenty-first century. Wisnovsky has written about these three scholars and their commentaries on Ibn Sīnā's al-Ishārāt in Wisnovsky, "Genealogy," $349 \mathrm{ff}$.

7 al-Asnawì asserts that not only was al-Tustarì a Shìì (kāna...räfidan), but also that he often skipped prayers (kāna...kathīr al-tark li-l-șalāt). Al-Rahim, maintaining that al-Tustarī was a Shäfíî, dismisses such accusations as a literary topos meant to diminish the authority of Shāfiîs who engaged in philosophy. 'Abd al-Rahīm ibn al-Ḥasan al-Asnawī, Ṭabaqāt al-Shāfíìyya, ed. Kamāl Yūsuf al-Ḥūt (Beirut: Dār al-Kutub al'Ilmiyya, 1987), 1:204, 154.13; Wisnovsky, “Genealogy,” 357, n29; Al-Rahim, Philosophical Tradition, 33.

8 Given that al-Asnawī considered al-Tustarī a Shīî̀ and included him in his Ṭabaqāt al-Shäfíiyya, alTahtānī's mere inclusion in that work is in itself not enough to conclude that he was a Sunnī.

$9 \quad$ Al-Rahim, Philosophical Tradition, 130-41.

10 'Umar Riḍā Kaḥhāla, Mu'jam al-mu'allifin tarājim muṣannifi l-kutub al-'arabiyya (Beirut: Mu'assasat alRisāla, 1993), 3:\#15575, 642; al-Lajna al-'ilmiyya fī mu'assasat al-Imām al-Ṣādiq, Mawsū'at țabaqāt al-fuqahä’, ed. Ja ‘far al-Subḥānī (Qum: Maktab al-Tawhịd, 1419 AH), 8:\#2831, 226-27; Khayr al-Dīn alZiriklī, al-A'ām: qāmūs tarājim li-ashhar al-rijāl wa-l-nisầ' min al-'arab wa-l-musta'ribìn wa-l-mustashriqīn (Beirut: Dār al-'Ilm li-l-Malāyīn, 2002), 7:38.

11 This study's findings are tentative and limited by the sources examined. Future research can assess their validity by exploring beyond țabaqāt and similar works, as well as Quțb al-Dīn's own works beyond his adjudicative commentary on Ibn Sīnā's al-Ishārāt, entitled al-Muhākama bayna al-Imām wa-l-Nașīr. 
and relayed different information about him. Shīî̀ scholars were overwhelmingly more concerned with addressing his sectarian affiliation, whereas Sunnī scholars either ignored the question or merely added the nisba al-Shāfî̀. Overall, despite the prominence ascribed to al-Taḥtānī today, the earliest sources, including those written by his contemporaries and near-contemporaries, are short on detail.

Section II presents a chronological overview of the relevant bio-bibliographical sources, in which I trace the unique and overlapping contributions that each scholar adds to our knowledge of al-Tahtānī. This section demonstrates how an abundance of sources actually contains little original information due to the ubiquitious practice among later scholars of copying, paraphrasing, and agglomerating earlier and popular sources. Section III then addresses the patterns in these sources. It reveals that Shìî sources - appearing in the seventeenth century and relying on testimonies from earlier Shìî̀ scholars - and Sunnī sources - appearing largely before the seventeenth century - are often in debate. They agree on some fundamentals about al-Taḥtānī's life and career, but disagree on who his teachers and students were and, especially, on his sectarian affiliation. The concluding section, Section IV, presents what we can say with confidence about al-Taḥtānī, returns to the question of whether he was a Sunnī or a Shìîi, and ultimately claims that the evidence suggests that he was a Sunnī.

\section{The Bio-bibliographical Sources}

\section{A. Eighth/Fourteenth-Century Sources}

Of the bio-bibliographical sources that I have examined, the first to contain notices concerning Quṭb al-Dīn were written by his contemporaries or near-contemporaries, among them al-Subkī, al-Asnawī, Ibn Rāfi', and Ibn Kathīr. All of them appear to have made entirely original contributions to our knowledge of him in that they did not borrow from each other. Al-Subkī and Ibn Kathīr both refer to their personal interactions with him. I present these notices, as well as all the others that follow, in order according to their author's death date.

The earliest, and at five lines one of the shortest, notice occurs in Tāj al-Dīn al-Subkī's (d. 771/1370) Țabaqāt al-Shāfíiyya al-kubrā. Al-Subkī begins by lauding al-Taḥtānī's mastery of the rationalist disciplines (al-ma'qūlāt) and remarking on 
his fame. ${ }^{12}$ He then notes that Quțb al-Din arrived in Damascus in 763/1361-62, adding that he personally studied with him and found him to have a keen mind. AlSubkī then lists al-Taḥtānīs publications and date of death (6 Dhu'l-Qa'dah 766/26 July 1365) before moving on to the next entry. ${ }^{13}$

Another contemporary of al-Taḥtānī, Jamāl al-Dīn al-Asnawī (d. 772/1370), made a similarly concise (about five lines) entry in his Țabaqāt al-Shāfíiyya. Al-Asnawìs entry stands out, however, for erroneously recording this scholar's ism as Mahmūd $;^{14}$ for being the sole source to give him the nasab Ibn Nizām al-Dīn; and, more importantly, for telling the story behind his sobriquet al-Tahtānī. This name became attached to him while he was studying at a madrasa in Damascus, where another Quṭb al-Dīn lived on an upper floor. ${ }^{15}$ This story reappears in a number of later sources. ${ }^{16}$

The next entry appears in Muhammad ibn Rāif' al-Sallāmī’s (d. 774/1372) alWafayāt. Originally from Egypt, Ibn Rāfi' accompanied his father to Damascus in 714/1314-15, though he did not settle there permanently until 739/1338-39. ${ }^{17}$ Though it is possible that Ibn Rāi' could have known al-Taḥtānī personally, he says nothing of this in his notice. In fact, this truly sparse notice (about seven lines) provides no more than al-Taḥtānī's name, to which he adds the kunya Abū 'Abd Allāh, ${ }^{18}$

12 al-Subkī was less boastful of al-Tahtānī’s knowledge of the traditional sciences. While he deemed alTahtānī an imām in the ma'qūlāt, he was merely "knowledgeable" of Qur'ānic exegesis, stylistics, and rhetoric ('ärifan bi-l-tafsīr wa-l-ma'ānī wa-l-bayān), and even less so of grammar (mushärikan fï l-naḥw). Tāj al-Dīn 'Abd al-Wahhāb ibn 'Alī al-Subkī, Ṭabaqāt al-Shāfíiyya al-kubrā, ed. 'Abd al-Fattāḥ Muhammad Ḥilw and Maḥmūd Muḥammad Ṭanāḥī (Cairo: Dār Iḥyā’ al-Kutub al-'Arabiyya, 1964), 9:\#1334, 275; trans. modified from Al-Rahim, Philosophical Tradition, 34, 135.

13 al-Subkī, Țabaqāt, 9:\#1334, 274-75. The text provides al-Taḥtānī's death date as 6 Dhu'l-Qa'dah/26 July 1365, which the editor emends, without explaining why, to 16 Dhu'l-Qa'dah/5 August 1365.

14 Al-Rahim suggests that this is due to the author's confusion with another famous Quṭb al-Dīn, i.e., al-Shīrāzī; Al-Rahim, Philosophical Tradition, 135 n480.

15 al-Asnawī, Țabaqāt al-Shāfíiyya, 1:155, \#296.

16 Abū Bakr ibn Aḥmad ibn Qāḍi Shuhba, Ṭabaqāt al-Shāfíiyya, ed. 'Abd al-'Alīm Khān (Haydarābād alDakan: Maṭba 'Majlis Dā’irat al-Ma‘ārif al-'Uthmāniyya, 1979), 3:\#674, 283; Aḥmad ibn 'Alī Ibn Hajar al-'Asqalānī, al-Durar al-kāmina fĩ a'yān al-mi'a al-thāmina (Beirut: Dār al-Jīl, 1993), 4:\#923, 339; 'Abd al-Raḥmān al-Suyūțī, Bughyat al-wu'àt fì țabaqāt al-lughawiyyīn wa-l-nuhāàt, ed. Muhammad Abū alFaḍl Ibrāhīm (Beirut: Dār al-Fikr, 1979), 2:\#1981; Aḥmad ibn Mușțafā Ṭaşköprīzade, Miftāḥ al-sa'āda wa-mișbāḥ al-siyāda fì mawựūāt al-'ulūm (Beirut: Dār al-Kutub al-'Ilmiyya, 1990), 1:275; Shams al-Dīn Muḥammad ibn 'Alī al-Dāwūdī, Ṭabaqāt al-mufassirīn, ed. 'Alī Muhammad 'Umar (Cairo: Maktabat Wahba, 1972), 2:\#582, 253; 'Abd al-Hayy ibn Ahmad Ibn al-'Imād, Shadharāt al-dhahab fĩ akhbār man dhahab (Beirut: Dār Ibn Kathīr, 1992), 8:355-56.

17 Ziriklī, al-A'tām, 6:124.

18 Several notices give al-Tahtānī the kunya Abū 'Abd Allāh. Rather than being multiple, independent attestations, however, this seems to be the result of the ubiquitous copying of sources and thus is likely unreliable. Abū 'Abd Allāh appears first in Ibn Rāfi', who is then copied by Abū Zur'a and Ibn Qādī Shuhba. The latter is then copied by al-Dāwūdī, Ibn Ṭūlūn, and Ibn al-'Imād. While it appears, therefore, 
place of death (the outskirts of Damascus) and burial (at the foot of Mt. Qāsyūn), list of works, a note that he moved to Damascus and worked there as a scholar, and a remark that he was pleasant and well-spoken (kāna hasan al-multaqā layyin al-kalima). ${ }^{19}$

Like al-Subkī, Ibn Kathīr (d. 774/1373) attests to personally meeting alTaḥtānī. I could find no reference to Quṭb al-Dīn in Ibn Kathīr's Ṭabaqāt al-fuqahā' al-shāfïiyyīn or his al-Bidāya wa-l-nihāya. It may be possible, nevertheless, to gain a sense of what Ibn Kathīr allegedly said based on what later scholars attributed to him. Ibn Qāḍi Shuhba and Ibn Hajar al-'Asqalānī both quote him to the effect that al-Tahtānī was wealthy ${ }^{20}$ and "singular among the mutakallimin in logic and the Greek sciences." ${ }^{21}$ Ibn Hajar's quote adds that al-Taḥtānī was well-spoken but had poor eyesight (kāna lațîf al-ỉbāra ḍa ìf al-'aynayn). He then relates an anecdote in which Ibn Kathīr tells of an alleged encounter between al-Subkīs father and alTaḥtānī. ${ }^{22}$ Al-Taḥtānī is said to have asked Taqī al-Dīn al-Subkī (d. 756/1355) about the hadīth, "Every newborn is born with an innate disposition."23 Al-Taḥtānī gave a refined and detailed criticism to Taqī al-Dīn's response (fa-naqaḍa huwa dhālika al-jawāb wa-bālagha fì al-taḥqì wa-l-tadqīq), after which the latter let loose in his counter-response (fa-ajābahū al-Subkī wa-ațlaqa lisānahū fỉhi), proclaiming that al-

that six sources attest to the name Abū 'Abd Allāh, in reality only one source does. Taqĩ al-Dīn Abū alMa'ālī Muḥammad al-Sallāmī Ibn Rāfi', al-Wafayāt, ed. Șāliḥ Mahdī 'Abbās and Bashshār 'Awwād Ma'rūf (Beirut: Mu'assasat al-Risāla, 1984), 2:299; Aḥmad ibn 'Abd al-Rahịm Ibn al-'Irāqī Abū Zur'a, al-Dhayl 'alā al-íbar fì khabar man 'abar, ed. Șālih Mahdī 'Abbās (Beirut: Mu'assasat al-Risāla, 1989), 184; Ibn Qāḍi Shuhba, Țabaqāt, 3:183; al-Dāwūdī, Țabaqāt, 2:253; Shams al-Dīn Muhammad ibn 'Alì Ibn Ṭūlūn, al-Qalāìd al-jawhariyya fī tārīkh al-Ṣālihiyya, ed. Muhammad Aḥmad Duhmān, (Damascus: Majma' alLugha al-'Arabiyya, 1980), 1:341; Ibn al-'Imād, Shadharāt al-dhahab, 1992, 8:355. It is worth noting that a different edition of Ibn al-'Imād's entry does not include Abū 'Abd Allāh; 'Abd al-Ḥayy ibn Ahmad Ibn al-'Imād, Shadharāt al-dhahab fi akhbār man dhahab (Cairo: Maktabat al-Qudsī, 1931), 5:207.

19 Ibn Rāfi', al-Wafayāt, 2:\#831, 299-300.

20 Wa-lahu māl wa-tharwa; Ibn Qāḍi Shuhba, Ṭabaqāt, 3:\#674, 283; Ibn Hajar al-'Asqalānī, al-Durar alkāmina, 4:\#923, 329.

21 Käna awhad al-mutakallimìn bi-l-manțiq wa-'ulūm al-awä'il. There is a slight variation between Ibn Hajar and Ibn Qāḍi Shuhba, whose text reads ahad instead of awhad, has al-'álimīn after al-mutakallimīn, and has 'ilm instead of 'ulūm. Ibn Qāḍi Shuhba, Ṭabaqāt, 3:\#674, 283; Ibn Hajarar al-'Asqalānī, al-Durar alkāmina, 4:\#923, 329.

22 I call the encounter "alleged" because Tãj al-Dīn al-Subkī does not mention in it in his entry on alTahtānī, despite mentioning that they studied together.

23 Kullu mawlūdin yūladu 'alä al-fițrati. This is how the hadìth appears in Ibn Hajar. In one of its versions, the full hadith continues: “Its [i.e., the newborn's] parents make him Jewish, or Christian, or Zoroastrian. This is just like how an animal produces [a perfect newborn] animal. Do you find it defective?" (faabawāhu yuhawwidānihi aw yunașșirānihi aw yumajjisānihi ka-mathali al-bahīmati tuntiju l-bahīmata hal tarā fih̄a jad'a'); Muhammad ibn Ismā'il Bukhārī, The Translation of the Meanings of Sahîh Al-Bukhâri: Arabic-English, trans. Muhammad Muhsin Khan (Riyadh: Darussalam, 1997), 2:\#1385, 267. Subkī's response appears in Muhammad al-Sayyid Abū 'Ammih, Kull mawlūd yūlad 'alā al-fițra (Dār al-Ṣahāba li-l-turāth, 1990). Thank you to the reviewer for alerting me to this. 
Taḥtānī was lacking in knowledge of the principles of Islamic law and possessed only a superficial knowledge of logic (nasabahū ilā 'adam fahm maqūṣid al-shar'ì wa-l-wuqūf ma'a zawāhir qawāìd al-manțiq). ${ }^{24}$ Al-Suyūțī (d. 911/1505), perhaps quoting Ibn Hajar, presents a somewhat truncated version of Ibn Kathïr's notice. ${ }^{25}$ al-Dāwūdī (d. 945/1538-39) offers the same truncated version. ${ }^{26}$ Lastly, according to Abū Zur'a, Ibn Kathīr noted al-Tahtānīs death date to be 7 Dhū l-Qa'da 766/27 July $1365 .{ }^{27}$ These few contemporary and near-contemporary sources evidently had very little to say about Quṭb al-Dīn.

\section{B. Ninth/Fifteenth-Century Sources}

In general, the farther removed we are from al-Tahtānì's lifetime, the longer the entries become because they borrow and quote from prior sources. This is not yet the case, however, for the Shāfi'i jurist Abū Zur'a (Ibn al-'Irāqī, d. 826/1423), whose entry amounts to a couple brief paragraphs. Born in Cairo in 762/1361, Abū Zur'a's life straddled the second half of the eighth/fourteenth and the first half of the ninth/fifteenth centuries. He studied in both Cairo and Damascus before beginning his career as a teacher and jurist in Cairo. ${ }^{28}$ While it would have been impossible for him to have met al-Taḥtānī, he could have heard about him directly from those who knew him. Nevertheless, he has little to say about him in his al-Dhayl 'alā al-íbar fí khabar man 'abar. He was, however, the first one to refer explicitly to al-Tahtāni's sectarian affiliation, including the nisba al-Shāfî̀. In contrast to al-Subkī, Abū Zur'a claims that Quțb al-Dīn was known to excel in jurisprudence (ușūl al-fiqh), Arabic, and logic. He quotes Ibn Rāfi' (without reference) to the effect that al-Tahtānī was pleasant and well-spoken. He also quotes Ibn Rāfi', together with Ibn Kathīr (this time with reference), about al-Taḥtānīs death date: either 6 Dhu'l-Qa'dah/26 July or 7 Dhu'l-Qa'dah/27 July, respectively. Abū Zur'a says that Ibn Kathīr is correct, but gives no reason for this assertion. ${ }^{29}$

25 al-Suyūțī, Bughyat al-wu'āt, 2:\#1981, 281. Unlike Ibn Ḥajar, al-Suyūțī does not mention that al-Taḥtānī was singular among the mutakallimin of his age in logic and the Greek sciences. His account also lacks reference to al-Taḥtānīs poor eyesight and wealth. The rest, however, matches up with Ibn Hajar's. al-Dāwūdī, Ṭabaqāt, 2:\#582, 253-54.

27 Abū Zur'a, al-Dhayl, 184-85.

28 K.S. Salibi, "Abū Zur'a," in Encyclopaedia of Islam, Second Edition, ed. P. Bearman et al. (Brill), accessed June 5, 2019, http://dx.doi.org/10.1163/1573-3912_islam_SIM_8279. Hereinafter abbreviated as EI2. 
The next source, al-Maqrīzì (d. 845/1442), was born in the year of al-Taḥtānī's death and is the first of several Cairene contemporaries to mention him. AlMaqrīzī's terse notice - a mere three lines in his al-Sulūk li-Ma'rifat Duwal al-Mulūk - mentions little more than al-Taḥtānī's age (died sometime in his 60s), that he excelled in logic and grammar, and two of his works: his commentary on al-Kātibỉ's al-Shamsiyya and his glosses on al-Zamakhsharī's (d. 538/1144) al-Kashshāf. ${ }^{30}$

Following al-Maqrīzì is the first source born after al-Taḥtānī's death, Ibn Qāḍi Shuhba (d. 851/1448), a teacher and a judge in Damascus. He included entries on Quțb al-Dīn in both his Țabaqāt al-Shāfïiyya and his Tārīkh. His entries - each almost three times as long as any preceding one - are a compilation of those by al-Subkī, al-Asnawī, Ibn Rāfi', and Ibn Kathīr. Like Abū Zur'a, he explicitly referred to al-Taḥtānī's sectarian affiliation, adding the nisba al-Shāfíi in the notice of his death. The notices in the Taqabāt and the Tärīkh are nearly identical. After acknowledging that some say his name was Mahmūd (without mentioning alAsnawī by name), Ibn Qāḍī Shuhba praises al-Taḥtānī (in both notices) as being "among the leaders in the rationalist disciplines" (ahadun min a'immat al-ma'qūl), a line that Ibn Hajar (d. 852/1449), al-Suyūțī (d. 911/1505), al-Dāwūdī (d. 911/1505), Ibn al-'Imād (d. 1089/1679), and al-Ișbahānī (d. 1130/1718) all repeat verbatim. Ibn Qāẹi Shuhba was the first to remark that al-Taḥtānī had studied under the Shāfíì jurist and Ash'arī theologian 'Aḍud al-Dīn al-Ījīi (d. 756/1355) before moving to Damascus. ${ }^{31}$

A contemporary of Ibn Qāḍī Shuhba and al-Maqrīzì, Ibn Hajar al-'Asqalānī (d. 852/1449), included an entry on al-Taḥtānī in his biographical dictionary of noteworthy individuals who died in the eighth/fourteenth century, al-Durar al-

30 Taqī al-Dīn Aḥmad ibn 'Alī al-Maqrīzī, al-Sulūk li-márifat duwal al-mulūk, ed. Muhammad 'Abd al-Qādir 'Ațā (Beirut: Dār al-Kutub al-'Ilmiyya, 1997), 4:280.

31 Ibn Qāḍi Shuhba, Țabaqāt, 3:\#674, 183-84; Ibn Qāḍi Shuhba, Tārīkh Ibn Qāḍ̄ Shuhba, ed. 'Adnān Darwīsh (Damascus: al-Ma'had al-Faransī li-l-Dirāsāt al-'Arabiyya, 1994), 3:267. Ibn Ḥajar quotes Ibn Qāḍī Shuba on al-Taḥtānī’s being a student of al-İjī. Al-Suyūṭi and Ibn al-'Imād then quote Ibn Hajar. Al-Khwānsārī quotes al-Suyūțī, while al-Ṭabarsī quotes al-Khwānsārī quoting al-Suyūṭî. Al-Dāwūdī and al-Ișbahānī quote Ibn Qāḍi Shuhba. Despite the many sources, Ibn Qāḍi Shuhba is effectively the only bio-bibliographical source for this detail of al-Taḥtānī's life. Ibn Hajar al-'Asqalānī, al-Durar al-kāmina, 4:\#923, 339; al-Suyūțī, Bughyat al-wu'āt, 2:\#1941, 281; al-Dāwūdī, Ṭabaqāt, 2:\#582, 253; Ibn al-'Imād, Shadharāt al-dhahab, 1992, 8:355; 'Abd Allāh ibn 'Īsā al-Iṣbahānī, Riyād al-'ulamā' wa-hiyād al-fuḍalā', ed. Aḥmad Ḥusaynī (Qum: Mațba'at al-Khayyām, 1980), 5:171; Muhammad Bāqir al-Khwānsārī, Rawựāt al-jannāt fì aḥwāl al-'ulamā' wa-l-sādāt (Tehran: al-Mațba'a al-Haydariyya, 1390 AH), 6:41; Husayn Taqī al-Nūrī al-Ṭabarsī, Khātimat Mustadrak al-wasā’il (Mu’assasat Āl al-Bayt li-Iḥyā' al-Turāth, n.d.), 2:360. 
Kämina fï A'yān al-Mi'a al-Thāmina. ${ }^{32}$ Like the others, the entry is brief; in fact, most of it is a direct quote from Ibn Kathīr. He also quotes Ibn Qāḍi Shuhba (without acknowledgement) on al-Taḥtānī being a leader in the rationalist disciplines and a student of al-İjī. He also adds, enigmatically, "and others" (akhadha 'an al-'Adud wa-ghayrih) ${ }^{33}$ and that after arriving in Damascus, al-Taḥtānī remained in the Zāhiriyya madrasa until his death. The fact that he taught at this madrasa strongly implies that he was a Sunnī. ${ }^{34}$ As did so many others, he quotes al-Asnawi on the story of Quṭb al-Dīn being known as al-Taḥtānī and on his having mastered many disciplines. The only scholar to follow al-Asnawī in calling him Mahmūd rather than Muhammad, he acknowledges that this goes against the opinions of Ibn Kathìr and Ibn Rāfi' ${ }^{35}$ In his annalistic history Inbā' al-Ghumr, Ibn Hajar claims that al-Taḥtānī was one of Sa'd al-Dīn al-Taftāzānī's (d. 792/1390) teachers. ${ }^{36}$

Like Ibn Hajar, the Cairene Ibn Taghrībirdì (d. 874/1470) also included an entry (amounting to five lines) on al-Taḥtānī in his history of Egypt, al-Nujūm al-Zāhira fĩ Mulūk Miṣr wa-l-Qāhira. Ibn Taghrībīrdì is the third of the scholars mentioned thus far to have included the nisba al-Shāfi'î in al-Taḥtānī's name. He very briefly praises him as being an "ocean of knowledge, especially in the rationalist sciences" (kāna bahran fì jamì' al-'ulūm lā-siyyamā fì 'ulūm al-'aqliyya) and lists his compositions. He also mentions one of his teachers, "al-'Allāma Shams al-Dīn al-Aṣbahānī," asserting that al-Taḥtānī's works were superior to those of his teacher. ${ }^{37}$ Ibn Taghribīrdī neither cited earlier sources on al-Taḥtānī nor, as far as I have seen, was cited by later scholars.

34 Only Shāfíî and Hanafī scholars were permitted to teach at the Zāhiriyya. Since nobody has claimed that he was a Hanafī, this would mean that al-Taḥtānī was a Shāfíi. My thanks to the reader for pointing this out to me.

35 Ibn Hajar al-'Asqalānī, al-Durar al-kāmina, 4:339. Ibn Rāfi' does not actually assert that al-Taḥtānī’s name is Mahmūid.

36 Madelung calls Ibn Hajar's notice on al-Taftāzānī unreliable. He argues that while it is possible that al-Taḥtānī and al-Taftāzānī were at the court of the Golden Horde Khāns at the same time, al-Taftāzānī would have been an established scholar and thus a colleague, rather than a pupil, of al-Tahtānī. W. Madelung, "Al-Taftāzānī," EI2, accessed July 24, 2018, http://dx.doi.org/10.1163/1573-3912_islam_ SIM_7296.

37 Abū l-Mahāsin Yūsuf Ibn Taghrībirdī, al-Nujūm al-zāhira fĩ mulūk Miṣr wa-l-Qāhira (Cairo: al-Mu'assasa al-Mișriyya al-'Amma li-l-Ta'lif wa-l-Tarjama wa-l-Ṭibā'a wa-l-Nashr, 1963), 11:87-88. The teacher is Maḥmūd b. 'Abd al-Raḥmān b. Aḥmad b. Muḥammad al-Aṣbahānī, also known as Abū al-Thanā' (d. 749/1349). He was a scholar first in Damascus, where he impressed Ibn Taymiyya, and then in Cairo. Ziriklī, al-A'lām, 7:176. Ṭaşköprīzade also mentions hìm as al-Taḥtānī’s teacher, saying that Ṭahtānī studied with him in Cairo in 740/1339-40. Țaşköprīzade, Miftāḥ al-sa'āda, 2:243. 
The last of the fifteenth-century sources is al-Suyūțīs (d. 911/1505) Bughyat al-Wu'àt. ${ }^{38}$ Its entry on al-Tahtānī is a pastiche of other notices. The bulk of it is a quotation from Ibn Kathīr that relates the encounter between al-Taḥtānī and Taqī al-Dīn al-Subkī. In addition to quoting al-Asnawī and Ibn Hajar, al-Suyūṭī also quotes his own teacher, Muhyyī al-Dīn al-Kāfiyajī (d. 879/1474), who said that alTaḥtānī was wise despite being imperfect in the Arabic sciences. ${ }^{39}$

\section{Tenth/Sixteenth-Century Sources}

First is Aḥmad b. Mușțafā Ṭaşköprīzade’s (d. 968/1561) Miftāḥ al-Sa'āda waMișbāh al-Siyāda. He opens his notice with what appears to be an original telling (in language, but not detail) of the story behind the name al-Taḥtānī. He then quotes al-Subkī's entire entry. Țaşköprīzade next adds, in what may be an original contribution, that al-Taḥtānī had raised his slave Mubārakshāh from his youth and educated until he became a learned professor. ${ }^{40}$

Al-Dāwūdī's (d. 945/1538-9) entry in Tabaqāt al-Mufassirīn combines the notices in Ibn Qāọī Shuhba (which includes quotations from al-Subkī, al-Asnawī, and Ibn Kathīr) and al-Suyūṭī (a paraphrastic account of al-Taḥtānī's encounter with Taqī al-Dīn). ${ }^{41} \mathrm{He}$ also inserts the same abbreviated version of al-Asnawī's explanation of the laqab al-Taḥtānī that appears in al-Suyūțī. ${ }^{42}$

Like al-Dāwudī, Ibn Ṭūlūn's (d. 953/1546) notice on al-Taḥtānī in al-Qalāid alJawhariyya is a partial copy of Ibn Qāḍi Shuhba's, but with minor deviations. ${ }^{43}$ Ibn Ṭulūn does, however, make one original and significant claim: That al-Taḥtānī was buried below Gabriel's cavern in the Khwārizmiyya mausoleum, as opposed to at the foot of Mt. Qāsyūn, according to Ibn Rāfí. ${ }^{4}$

al-Suyūțī, Bughyat al-wu'àt, 2:\#1981, 281.

Ṭaşköprīzade quotes al-Suyūṭi on this; Țaşköprīzade, Miftāh al-sa'āda, 1:193.

Ṭaşköprīzade, Miftāh al-sa'äda, 1:275. Al-Rahim identifies the slave as Shams al-Dīn Muhammad ibn Mubārakshāh al-Bukhārī. Al-Rahim, Philosophical Tradition, 134. Țaşköprīzade also reports that while still in Rayy, al-Taḥtānī desired to meet 'Ubayd Allāh b. Mas'ūd al-Maḥbūbī (Șadr al-Sharī'a al-Aṣghar/ al-Thānī, d. 747/1346). Though al-Taḥtānī sent Mubārakshāh to Herat to meet him first, Mubārak Shāh advised against going to meet him. Țaşköprīzade, Miftāḥ al-sa'āda, 2:171.

It is the very same paraphrase that appears in Suyūtī's entry, except that al-Dāwūdī explicitly mentions that Taqī al-Dīn was al-Taḥtānī's interlocutor.

al-Dāwūdī, Țabaqāt, 2:\#582, 253-54.

Ibn Ṭūlūn does not mention that some say al-Taḥtānī’s name was Maḥmūd. He also excises Ibn Qāḍi Shuhba's observation that al-Tahtānī mastered the rationalist sciences, had a general knowledge of Islamic religious sciences, was a student of al- $\overline{\mathrm{j}} \mathrm{j} \overline{\mathrm{i}}$, and that he resided in Damascus until his death.

Ibn Țülūn, al-Qalä'id, 1:341. On the significance of this claim, see al-Rahim, Philosophical Tradition, 137. 


\section{Eleventh/Seventeenth-Century Sources}

Up to this point, the sources that I have examined have all come from Shäfíi if they have anything to say at all on this and Hanafĩ scholars, all of which say that alTaḥtānī was a Shāfi'î. Having arrived in the seventeenth century, we now find sources composed by Shîîi scholars who claim that Quṭb al-Dīn was a Shīîi. The first is Qādị Nūr Allāh al-Shushtarìs (d. 1019/1610) Majālis al-Mu’minīn, which praises al-Taḥtānī extensively in poetry and prose, mentions that he was born and raised in Warāminn, ${ }^{45}$ and claims that he descended from Āl Buwayh. More significantly, al-Shushtari is the first one to quote from what he alleges to be al-'Allāma al-Hillì's (d. 726/1325) ijāza permitting al-Taḥtānī to transmit his works. ${ }^{46} \mathrm{He}$ also quotes what he claims to be a statement by Muhammad ibn Makki (d. 786/1384) ${ }^{47}$ to the effect that he entered alTaḥtānī's service in Damascus and received permission to transmit from him.

Ibn Makkī affirms that al-Taḥtānī was "without a doubt" (bì shubha) a Shīîi, averring that al-Taḥtānī spoke about this unequivocally (tașrīh ba-ān mîfarmūd); additionally, his devotion to his teacher al-Hilli apparently made this affiliation clear. Ibn Makkī also reports that al-Taḥtānī died on 12 Dhu'l-Qa'dah 766/1 August 1365 and that he was first bured in Șalihịyya but later moved to an undisclosed location. Beyond this, al-Shushtarī refers to al-Suyūțīs telling of the encounter between al-Taḥtānī and Taqī al-Dīn al-Subkī, which itself is a truncated version of Ibn Ḥajar's transmission of Ibn Kathïr's account. ${ }^{48}$

Next is al-Tafrishì (d. after 1030/1620), whose short entry in his Naqd al-Rijāl adds the nasab Ibn Bābawayh to al-Taḥtānīs lineage. ${ }^{49}$ He even gives al-Taḥtānī another nasab, Ibn Abī Ja'far, ${ }^{50}$ likely a variant of the kunya Abū Ja'far. ${ }^{51}$ Like al-

C. E. Bosworth, "Warāmīn," EI2, accessed May 24, 2019, http://dx.doi.org/10.1163/1573-3912_ islam_COM_1338.

46 See the translation in al-Rahim, Philosophical Tradition, 132.

47 Known as al-Shahīd al-Awwal. B. Scarcia Amoretti, "Muhammad b. Makkī," EI2, accessed June 6, 2019, http://dx.doi.org/10.1163/1573-3912_islam_SIM_5361.

48 Nūr Allāh ibn 'Abd Allāh al-Shushtarī, Kitāb-i Mustațāb-i Majālis al-mu’minīn (Tehran: Kitābfurūshī-yi Islāmiyya, 1995), 2:212-13.

49 Only two other scholars refer to al-Tahtānī as Ibn Bābawayh: al-Ardabīlī and al-'Āmilī, both of whom copied al-Tafrishī.

50 Mușțafā ibn al-Ḥusayn al-Tafrishī, Naqd al-rijāl (Qum: Mu'assasat Āl al-Bayt li-Ihyā’ al-Turāth, 1418 AH), 4:311. Copying al-Tafrishī are Muhammad ibn 'Alī al-Ardabīlī, Jāmi' al-ruwāt wa-izāhat alishtibāhāt 'an al-țuruq wa-l-asnād (Qum: Maktabat Āyat Allāh al-'Użmā al-Mar'ashī al-Najafī, 1403 AH), 2:187, and Muḥammad ibn Ismāî̀l al-Māzandarānī Abū 'Alī al-Ḥāirī, Muntahā l-maqāl fí aḥwāl al-rijāl (Qum: Mu'assasat Āl al-Bayt, 1995), 6:175. Zayn al-Dīn ibn 'Alī’s ijāza to al-Ḥusayn 'Abd al-Ṣamad also has "Ibn Abī Ja'far." Muhammad Bāqir al-Majlisī, Biḥār al-anwār al-jāmi'a li-durar akhbār al-a'imma alațhār (Beirut: Mu'assasat al-A'lamī li-l-Mațbū'āt, 2008), 105:99.

51 Abū Ja'far appears first in 'Alī al-Karakī’s ijāza to al-Qāḍi Ṣafī al-Dīn, al-Majlisī, Biḥār, 105:49; and later in al-Khwānsārī, Raw ḍāt al-jannāt, 6:380; al-Ṭabarsī, Khātimat, 2:351. 
Shushtarī, he reports that al-Hillī was al-Taḥtānī's teacher and that Muhammad ibn Makkī was his student. Al-Tafrishī calls Quțb al-Dìn a luminary among the Shìî̀s (wajhun min wujūhi hādhihī al-țā'ifa) who enjoyed high esteem and rank (jalīl al-qadr wa-'azīm al-manzila). Aside from calling al-Taḥtānī a Shī'ì, al-Tafrishī stands out from everyone I have reviewed thus far in that he neither copied from nor referred to any of them in composing his notice. ${ }^{52}$

Another scholar to break the mold is Hājjì Khalífa (Kātib Çelebi, d. 1067/1657), who mentions al-Taḥtānī when discussing Ibn Sīnā's (d. 428/1037) al-Ishārāt wal-tanbīhāt. According to him, al-Taḥtānī wrote his Muḥākamāt supercommentary at the suggestion of Quṭb al-Dīn al-Shīrāzì (d. 710/1311). Al-Rahim convincingly argues, however, that we can dismiss reports of al-Rāzī and al-Shīrāzī meeting due to their significant age difference and the vast geographical distance between them at the time when they could possibly have met. Hājjī Khalifa had nothing else to say here about al-Taḥtānī. ${ }^{53}$

The next source, the Hanbali Ibn al-'Imād's (d. 1089/1679) Shadharāt al-Dhahab, returns to the well-formed mold. The beginning of his notice on al-Taḥtānī, after stating his name, is the same as al-Dāwūdī's, which was nearly identical to Ibn Qādī Shuhba's. Ibn al-'Imād inserts kāna shāfïiyyan, an explicit assertion of his Shāfi'î affiliation, after Quṭb al-Dīn's name and the explanation of al-Taḥtānī as found in al-Dāwūdī. He then quotes Ibn Hajar's transformation of Ibn Qāḍi Shuhba on al-Taḥtānī's having studied with al-ījī and others, al-Suyūṭi quoting his teacher alKāfiyajī, most of al-Subkī's entry, and Ibn Rāfi' on al-Taḥtānī’s place of burial. ${ }^{54}$

After Ibn al-'Imād comes al-Ardabīlī (d. 1098/1686-87), who copies his notice in his Jāmi' al-Ruwāt verbatim from al-Tafrishī. ${ }^{55}$ Al-'Āmilī (d. 1104/1693), in his Amal al-Āmil, also quotes al-Tafrishī in full. Additionally, he is the first to quote alShushtarī’s Majālis al-Mu'minīn on al-Taḥtānī’s ijāza from al-Hillī. ${ }^{56}$

Muhammad Bāqir al-Majlisī (d. 1110/1698) follows the path blazed by alShushtarī. His contribution in his Biḥār al-Anwār relies heavily on al-Taḥtānī's

53 Mușțafā 'Abd Allāh al-Qusțanținī Kātib Çelebi Ḥājjī Khalīfa, Kashf al-ẓunūn 'an asāmī al-kutub wa-lfunūn (Beirut: Dār al-Fikr, 1982), 1:95; al-Rahim, Philosophical Tradition, 22-23.

54 Ibn al-'Imād, Shadharāt al-dhahab, 1992, 8:355-56.

55 al-Ardabīlī, Jāmi', 2:187.

56 Muḥammad ibn al-Ḥasan al-Ḥurr al-'Āmilī, Amal al-āmil, ed. Aḥmad Ḥusaynī (Qum: Dār al-Kitāb alIslāmī, n.d.), 2:\#908, 300-1. 
ijāza from al-Hillī and on Ibn Makkî's statement about his time with al-Taḥtānī. In similar fashion to al-Shushtarīs report of Ibn Makkī's statement, al-Majlisī's version claims that al-Taḥtānī was without a doubt (bi-ghayri shakkin wa-lā rayb) a Shī'î, that he had personally heard al-Taḥtānī unequivocally attest to that (șarraha bi-dhālika wa-sami'tuhü minhu), and that his devotion to the ahl al-bayt (rather than al-Hillī) was well known. ${ }^{57}$ Unlike al-Shushtarī's statement, al-Majlisī's version specifies that Ibn Makkī met al-Taḥtānī in Damascus near the end of Sha'bān 766/May 1365. ${ }^{58}$

\section{E. Twelfth/Eighteenth-Century Sources}

Sources from the twelfth/eighteenth century continue the trends of borrowing from earlier sources and relying on the statements ascribed to al-Hillī and Ibn Makkī. The entry in 'Abd Allāh al-Iṣbahānī's (d.1130/1718) Riyāẹ al-'Ulamā’59 is a patchwork of earlier notices and information from ijāzāt. He copies al-'Āmilì's entire notice (which copies al-Hillī's ijāza as it appears in al-Shushtarī), Ibn Makkī's statement about meeting al-Taḥtānī in Damascus, ${ }^{60}$ Ibn Qāḍi Shuhba's notice, an excerpt from Jalāl al-Dīn al-Dawānī’s (d. 908/1502) ijāza to Mīr Husayn Maybudī (d. 909/1503-4), and an ijāza from Zayn al-Dīn ibn 'Alī (al-Shahīd al-Thānī, d. 965/1557-58 or 966/1558-59) to al-Husayn 'Abd al-Ṣamad (d. 984/1576). ${ }^{61}$ According to al-Dawānī's ijāza, al-Taḥtānī studied the rationalist sciences (al'aqliyyāt) under Quṭb al-Dīn al-Shīrāzì (d. 710/1311), while al-Sharīf al-Jurjānī (d. 816/1413) studied them under al-Taḥtānī. ${ }^{62}$

57 al-Majlisī, 104:378.

58 al-Majlisī’s version of Ibn Makkī's statement agrees with al-Shushtarī's version in that al-Tahtānī died on 12 Dhu'l-Qa'dah 766/1 August 1365, was buried at Ṣālihiyya, and then moved to an undisclosed location. Al-Majlisī, 104:377-78. Another less reliable statement ascribed to Ibn Makkī, this time in his ijāza to Ibn Khāzinn, says that he entered al-Taḥtānīs service in Damascus in 768/1367, after the date by which al-Taḥtānī is commonly said to have died. Al-Majlisī, 104:406.

59 Ișbahānī, Riyāḍ, 5:168-72.

60 This is the version as it appears after al-Majlisī produces al-Hillì's ijāza (rather than Ibn Makkī's ijāza to Ibn Khāzin). Al-Iṣbahānī claims to have seen this in the handwriting of Zayn al-Dīn ibn 'Alī, who claims to have seen it in Ibn Makkì's handwriting; al-Ișbahānī, 5:170.

61 Al-Ḥusayn 'Abd al-Ṣamad was the son of the Imāmī scholar Muhammad ibn Husayn (Bahā' al-Dīn al-'Ámilī, d. 1030/1621). Zayn al-Dīn ibn 'Alī authorizes him to transmit the commentary on alShamsiyya by al-Taḥtānī, whom he refers to as "Quṭb al-Dīn...ibn Bābawayh;” al-Majlisī, Biḥār, 105:99.9.

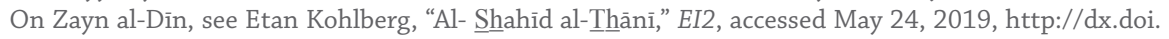
org/10.1163/1573-3912_islam_SIM_6763.

62 al-Iṣbahānī, Riyād, 5:170. Al-Rahim characterizes a meeting between al-Taḥtānī and Jurjānī as possible but likely legendary. Al-Rahim, Philosophical Tradition, 133-35. 
Like al-Ișbahānī, Yūsuf ibn Aḥmad al-Baḥrānī's (d. 1186/1772) entry in Lu'lu'at al-Bahrayn is a compilation of earlier sources: a partial copy of al-'Āmilī and a full copy of al-Shushtarī (translated into Arabic). At the end, al-Bahrānī adds his evaluation of whether al-Taḥtānī was a Shīîi: To claim that he was not a Shīîi because he lived outwardly as a Sunnī when in Syria is far-fetched (ba'ìd ghāyat al-bu'd), because Syria was then full of Shìî scholars who, performing taqiyya, lived publicly as Sunnīs. ${ }^{63}$

Closing out the twelfth/eighteenth-century sources are Muhammad Bāqir alBihbahānīs (al-Wahịid al-Bihbahānī, d. 1206/1791-92 or 1208/1793-94) Ta'lìqa 'alā Minhāj al-Maqāl and Abū 'Alī al-Ḥāirī's (d. 1216/1800-1) Muntahā al-Maqāl. AlBihbahānī's notice is an unacknowledged reproduction of al-Tafrishì's. ${ }^{64}$ Al-Hāàirī also copies al-Tafrishī's entire entry, but acknowledges doing so. He then copies the part of Ibn Makkīs ijāza to Ibn Khāzin, in which he mentions entering al-Taḥtānī's service, and the very beginning of al-Hillì's ijāza to al-Taḥtānī. ${ }^{65} \mathrm{Al}-\mathrm{H}$ ā'irī opines that associating al-Taḥtānī with Ibn Bābawayh is mistaken, as he is descended from the $\overline{\mathrm{A}} \mathrm{l}$ Buwayh; however, he gives no explanation as to why this is the case.

\section{F. Thirteenth/Nineteenth-Century Sources}

The two thirteenth/nineteenth-century sources that I have examined stand out from previous sources in their focus on debating al-Tahtānī's sectarian identity; both otherwise rely heavily on copying earlier sources. Muhammad Bāqir al-Khwānsārī al-Iṣbahānī (d. 1313/1895-96) dissents from his fellow Shī'îs by forcefully claiming in Raw ḍàt al-Jannāt that al-Tahtānī was not a Shī'ī. ${ }^{66}$ In fact, he was the first scholar to broach seriously the question of al-Tahtānī's sectarian affiliation. His entry fills ten pages in the modern printed edition. Its length is largely due to his extensive verbatim inclusion of material from al-Suyūțī, al-'Āmilī, and al-Bahrānī, which amounts to approximately 60 percent of the entry.

Al-Khwānsārī's strident and prolix entry receives an equally strident and even longer rebuttal from Husayn al-Nūrī al-Ṭabarsī (d. 1320/1902). Before addressing al-Khwānsārī specifically in his Khātimat Mustadrak al-Wasā'il, ${ }^{67}$ he begins with al-'Ulūm (Manama: Maktabat Fakhrāwī, 2008), \#74, 187-92.

64 The only version of Bihbahānī's Ta'lìqa available to me is Ta'līqa 'alā Minhāj al-maqāl, n.d., \#2962, 327, http://shiaonlinelibrary.com/الكتب.

65 al- Hâa'irī, Muntahā l-maqāl, 6:\#2849, 175-76. The ijāzas that al-Hāàirī quotes both appear in al-Majlisī. Al-Majlisī, Biḥār, 104:377-78, 406.

66 al-Khwānsārī, Raw ḍāt al-jannāt, 6:\#559, 38-48.

67 al-Ṭabarsī, Khātimat, 2:351-99. 
the familiar sources, reproducing al-Hillì's ijāza and Ibn Makkī's testaments to al-Taḥtānī’s being a Shī'î̀, as they appear in al-Majlisī. He alludes to the evidence found in al-Shushtarī's and al-'Āmilī's works, but says that the contemporaneous, eye-witness testimony by al-Tahtānī's student Ibn Makkī suffices to establish that al-Taḥtānī was a Shīîi. In a clear, if unacknowledged, response to al-Khwānsārī, alṬabarsī discounts the relevance and credibility of assertions that al-Tahtānī never demonstrated, whether in word or deed, being a Shī'i by pointing to the fact that Syria was then controlled by Sunnīs. One naturally would have dissimulated one's true beliefs in that situation, he observes. ${ }^{68}$ When he finally addresses al-Khwānsārī directly, al-Ṭabarsī mounts a point-by-point response, encompassing thirty-seven points and thirty-five printed pages (I address this in the end of the next section). ${ }^{69}$

\section{Patterns in the Sources}

Despite the abundance of biographical sources with entries on Quṭb al-Dīn, only a few of them make unique, original claims about him: al-Subkī (d. 769/1368), al-Asnawī (772/1370), Ibn Rāfi‘ (774/1372), Ibn Kathīr (d. 774/1373), Abū Zur'a (826/1423), Țaşköprīzade (d. 968/1561), al-Shushtarī (1019/1610), and alMajlisī (1110/1698). In other words, mainly al-Tahtānī’s contemporaries or nearcontemporaries and the first of several Shīî̀ scholars to cite the ijāzāt by al-Hillī and Ibn Makkī to construct his biography and prosopography. The majority of sources merely copy and repackage what came before them.

The most cited Sunnī scholar is al-Asnawī, who appears in seven later sources. ${ }^{70}$ His notice on Quṭb al-Dīn is hardly a paragraph. He was quoted so often due to the later Sunnī scholars' preference for his explanation of Quṭb al-Dīn's laqab, alTaḥtānī; no Shīîi scholar referred to Quṭb al-Dīn as al-Taḥtānī, though al-Iṣbahānī mentioned the name when he quoted Ibn Qādī Shuhba, who quoted al-Asnawī. With six scholars quoting his Ṭabaqāt al-Shāfíiyya, Ibn Qāḍi Shuhba (d. 851/1448) was the second most popular of the Sunnī scholars. ${ }^{71}$ The popularity of his work helped prolong the life of some earlier notices on al-Taḥtānī. Those by al-Subkī and

69 For a brief summary of some of al-Khwānsārī's arguments, see al-Rahim, Philosophical Tradition, 137-38.

70 directly by Ibn Qāḍi Shuhba, Țabaqāt, 3:\#674, 283; Ibn Hajar al-'Asqalānī, al-Durar al-kāmina, 4:\#923, 339; indirectly by al-Suyūțī, Bughyat al-wu'āt, 2:\#1981, 281; Ṭaşköprīzade, Miftāh al-sa'āda, 1:275; alDāwūdī, Țabaqāt, 2:\#582, 253; Ibn al-'Imād, Shadharāt al-dhahab, 1992, 8:355; al-Iṣbahānī, Riyāẹ, 5:171.

71 Ibn Ḥajar al-'Asqalānī, al-Durar al-kāmina, 4:\#923, 339; al-Suyūțī, Bughyat al-wu'āt, 2:\#1981, 281; alDāwūdī, Țabaqāt, 2:\#582, 253; Ibn Țūlūn, al-Qalāid, 1:341; Ibn al-'Imād, Shadharāt al-dhahab, 1992, 8:355; al-Ișbahānī, Riyāẹ, 5:171. 
Ibn Kathīr appear in four later sources; however, in three of those instances the later source is actually quoting Ibn Qāḍi Shuhba. ${ }^{72}$ At the other end of the spectrum, no later sources quoted Abū Zur'a, al-Maqrīzī (d. 845/1442), Ibn Taghrībirdī (d. 874/1470), Ibn Ṭūlūn (d. 953/1546), or Ibn al-'Imād (d. 1089/1679).

In addition to revealing who was quoting whom, my survey of the sources on al-Tahtānī's life uncovered some noteworthy patterns. All of the sources prior to the eleventh/seventeenth share certain characteristics and say essentially the same thing. First, almost all of them were written by Shäfi'i scholars, the two exceptions being the Hanafīs Ṭaşköprīzade (d. 935/1529) and Ibn Ṭūlūn. Of the fourteen eleventh/ seventeenth century sources that I examined, only six comment on al-Tahtānī's sectarian affiliation. Four of those were explicit, meaning they either included a nisba (like al-Shāfici ${ }^{\prime}$ ) or declared that he was a Shāfíi in the main text. By implicit, I refer to al-Subkī and al-Asnawī, both of whose works bore the title of Tabaqāt al-Shāfï ìyya, but who did not otherwise comment on his sectarian affiliation. Overall, such implicit assertions are weak evidence for the case that al-Taḥtānī was a Shāfíì Sunnì.

I claim that these works all said essentially the same thing because of the ubiquitous practice of copying and aggregating earlier sources. Ibn Qādị Shuhba contributed nothing original to our knowledge of Quṭb al-Dìn, as his entry merely combines what appear to be the only sources from the eighth/fourteenth century: al-Subkī, al-Asnawī, Ibn Rāfi', and Ibn Kathīr. Ibn Hajar al-'Asqalānī (d. 852/1449) then repackaged these sources. Both of these scholars account for most of the material that appears in Sunnì sources in the tenth/sixteenth and eleventh/ seventeenth centuries.

Major changes happen in the eleventh/seventeenth century, which saw many new claims being made about al-Taḥtānī, such as Shīî̀ scholars adding the nasabs Buwayhī $\bar{i}^{73}$ or Ibn Bābawayh. ${ }^{74}$ These changes begin with al-Shushtarī (d. 1019/1610), the earliest among the many Shìî sources for al-Taḥtānī's life that I have found. Al-Shushtarī was the first to proclaim that al-Taḥtānī was a Shīî̀. From this point on, all but two of the sources that I have examined were written by Shi'îs and make this same claim. The exceptions are the Hanbalī Ibn al-'Imād (d.

72 Ibn Ḥajar al-'Asqalānī, al-Durar al-kāmina, 4:339; Ibn al-'Imād, Shadharāt al-dhahab, 1992, 8:355; alIșbahānī, Riyāḍ, 5:171.

73 al-Shushtarī, Majālis, 2:212; Muhammad ibn Makkī's ijāza to Ibn Khāzin, al-Majlisī, Bihāar, 104:406; al-'Āmilī, Amal al-āmil, 2:300; al-Iṣbahānī, Riyāẹ, 5:168; al-Baḥrānī, Lu’lu'at Baḥrayn, 188; al-Ṭabarsī, Khātimat, 2:351.

74 Zayn al-Dīn ibn 'Alī's ijāza to al-Ḥusayn 'Abd al-Ṣamad, al-Majlisī, Biḥār, 105:99; al-Tafrishī, Naqd al-rijāl, $4: 311$. 
1089/1679), who claimed in his Shadharāt al-Dhahab that al-Taḥtānī was a Shāfî̀ì, and the Ḥanafị Ḥājjī Khalīfa (Kātib Çelebi, d. 1067/1657), who said nothing about this matter. Only one source written by a Shīîi, al-Khwānsārìs (d. 1313/1895-6) Rawd̄at al-Jannāt, disputes this assertion.

More significantly, al-Shushtari was the first one to go outside the biographical literature for information. He relied instead on what he claimed to be an ijāza from al-Taḥtānī's teacher, al-'Allāmī al-Ḥillī (d. 726/1325), and testimony from one of his students, Muhammad ibn Makkì (d. 786/1384). Later in the eleventh/seventeenth century, al-Majlisī (d. 1110/1698) would do the same, including the ijāzät from alḤillī and Ibn Makkī in his massive Bihāar al-Anwār.

Quțb al-Dīn's sectarian affiliation only became the subject of debate in the biobibliographical literature of the twelfth/nineteenth century - five centuries after his death. Prior to that, however, there are signs that scholars were discussing it. In a statement that first appears in al-Shushtari and resurfaces in similar form in al-Majlisī, al-Bahrānī’s (d. 1186/1772) Lu'lu'at al-Baḥrayn, and al-Iṣbahānī's (d. 1130/1718) Riyāẹ al-ulamä', Ibn Makkī affirms that al-Taḥtānī "was, without any doubt or uncertainty, of the Imāmì school. He spoke unequivocally about that, something I heard him say. His devotion to the rest of the People of the House is known." ${ }^{75}$ In al-Shushtarî's and al-Bahrānī's version, al-Taḥtānīs commitment to his teacher al-Hillì and the purity of his belief are presented as sufficient evidence to prove that he was a Shīi $\mathrm{i}^{76}$ Assuming that this statement is genuine, it suggests that within al-Tahtānīs lifetime or shortly after his death, his alleged student Muhammad ibn Makki felt it necessary to assert in no uncertain terms that alTaḥtānī was a devoted Shīī of pure belief.

At the very least, this statement indicates that this was relevant to Quțb al-Din's biography (as written by Shîî scholars) by the time al-Shushtarĩ first included it in the late ninth/sixteenth or early tenth/seventeenth century. More broadly, it was relevant to Safavi-era Shīî scholars engaged in a project of establishing a chain of transmission of philosophical knowledge, connecting prominent Shîi scholars all the way back to al-Shaykh al-Ra'îs, Ibn Sīnā. To support this chain, al-Taḥtānī needed to have been a Shīî and to have met other prominent Shī'a, like Quțb al-Dīn al-Shīrāzī. ${ }^{77}$ 
One scholar who disputed Ibn Makkī's statement was al-Khwānsārī. According to him, the source of the confusion about al-Tahtānī's sectarian affiliation is Ibn Makkī's declaration that al-Taḥtānī was an avowed Shī'î. He asserts that it is no more than an example of prudent dissimulation. ${ }^{78}$ In his response to al-Khwānsārī, al-Ṭabarsī finds this line of argumentation quite strange. He rebuts that observing taqiyya "requires considering an Imāmī to be a Sunnī ['add al-imāmì mukhālifan], not considering the head scholar among them [i.e., Sunnīs]...to be a Shīîi [muwāfiqan]." In other words, how could Ibn Makkī, whose sectarian affiliation is not in doubt, be engaging in taqiyya by unequivocally claiming that al-Taḥtānī, who al-Khwānsārī claims was the head Sunnī scholar in Damascus, is a Shīîn? al-Ṭabarsī asks: Would not taqiyya entail claiming that a Shìî̀ was a Sunnī ? He adds that it would be stupid and laughable to argue that al-Hilli was also engaging in taqiyya when praising alTaḥtānī in his ijāza (something which al-Khwānsārī does not actually argue). ${ }^{79}$

What al-Khwānsārī does do, however, is attack the reliability of al-Hillì’s ijāza. He asserts that it is suspicious that its transmission is limited to its appearance in al-Shushtarī's Majālis al-Mu'minīn, whose word, he claims, is unreliable. ${ }^{80}$ al-Ṭabarsī responds by claiming the opposite: al-Shushtarī was among the most pious and devoted Shīîi scholars, one whose word is not suspect in the least. (Neither offers any support for his claim.) Furthermore, he observes that the transmission of alHillī's ijāza is not limited to al-Shushtarì by pointing to its occurrence in al-Majlisī's Biḥār al-Anwār. Al-Ṭabarsī adds that even better evidence for al-Taḥtānī being a Shī'î is what Ibn Makkī says in his ijāza to Ibn Khāzin, which, he notes, appears in Bihār al-Anwār and "other sources." And yet he neglects to name these other sources, acknowledge that al-Majlisī is posterior to al-Shushtarī, or recognize that it is worth asking why the best evidence for al-Taḥtānī's being a Shî̀î is not widely attested until 250 years after his death. ${ }^{81}$

Al-Khwānsārī argues that even if one accepts that al-Tahtānī was a Shīî̀ while a student of al-Hilli, this does not negate the fact that he later converted and became the Sunnīs' chief scholar. ${ }^{82}$ al-Ṭabarsī responds by claiming that, to his knowledge, no Shī'î scholar who had reached the heights of knowledge had ever "left the light for 
the shadows" - meaning Shī'ism for Sunnism - just for the sake of worldly benefits, like being a chief scholar. He correctly reiterates that no source claims that al-Taḥtānī was the Sunnīs' chief scholar in Damascus. Al-Ṭabarsī then suggests that, had alTaḥtānī been a Sunnī, he would have appeared in those biographical dictionaries composed by Sunnīs. After observing that al-Taḥtānī does not appear in al-Kutubī's (d. 764/1363) Fawät al-Wafayāt, he adds an outlandish claim that is worth quoting in full: "Likewise, Ibn Ḥajar al-'Asqalānī did not mention him in his al-Durar al-Kāmina fï A'yān al-Mi'a al-Thāmina; nor does his [i.e.,. Al-Tahtānī's] contemporary, the chief judge in Syria, Tāj al-Dīn al-Subkī [mention him] in his Ṭabaqāt al-Shāfíiyya. I have not come upon these two books. But even if there were an entry for him in either of them, al-Suyūți would have mentioned it in his al-Ṭabaqāt." ${ }^{83}$ As we have seen, both al-Subkī and Ibn Ḥajar have notices on al-Taḥtānī. Moreover, al-Suyūṭī quotes Ibn Hajar (albeit without acknowledgment). Embarrassing as this oversight may be, al-Ṭabarsìs broader point stands: If al-Taḥtānī had been the head Sunnī scholar in Damascus, would not his contemporary al-Subkī have said as much?

Overall, neither party makes a convincing argument. Al-Khwānsārī relies heavily on suggestion and provides little actual evidence. Al-Ṭabarsī is often successful at pointing this out, but hurts his own cause by repeatedly making empirical assertions that are easily gainsaid. At the end of their lengthy entries on al-Tahtānī, one still lacks a satisfactory answer to the one persuasive piece of evidence marshalled by al-Khwānsārī, namely, that it takes centuries for Ibn Makkīs and al-Hillì’s ijāzāt to appear in the sources on al-Taḥtānī.

Even if Shîîischolars, aside from al-Khwānsārī, were certain that al-Taḥtānī was one of them, they were uncertain as to his lineage: Was he descended from Ibn Bābawayh al-Ṣadūq (d. 381/991), one of the earliest and most prominent Imāmī scholars, or the Âl Buwayh, the Daylamite dynasty that ruled Baghdad from 320/454-932/1062? Proponents of the first lineage claim various evidence to support it. According to al-Āmilī, Zayn al-Dīn ibn 'Alī (al-Shahìd al-Thānī, d. 965/1557-58 or 966/155859) stated as much in his ijāzāt. ${ }^{84}$ In al-Majlisī, one finds al-Taḥtānīs lineage, which indicates his descent from Ibn Bābawayh. The lineage is attributed to Muhammad ibn

83 Wa-kadhā lam yadhkurhu ayḍan Ibn Hajar al-'Asqalānī fĩ al-Durar al-kāmina fĩ a'yān al-mi'a al-thāmina walā mu'ạșiruhu qāộ̄ al-quḍāt bi-l-Shām Tāj al-Dīn al-Subkī fì kitāb Țabaqāt al-Shāfíiyya wa-lam na'thur 'alā al-kitābayni lākin law kāna lahu tarjamatun fì ahadihimā la-dhakarahu al-Suyūțī fì al-Ṭabaqāt. Al-Ṭabarsī, Khātimat, 2:379. That al-Ṭabarsī makes such a wildly incorrect claim underscores the extent to which much of his argument that al-Tahtānī was a Shīîi is weak and circumstantial. 
Makkī, who is said to have written it in the colophon of al-Taḥtānìs copy of Qawāid alAḥkām. It goes back only one generation before claiming al-Taḥtānìs ultimate descent: Muhammad ibn Muhammad ibn Abī Ja'far ibn Bābawayh. This seems insufficient to support Ibn Makki's claim that "this shows that he is among the children of alȘadūq Ibn Bābawayh." ${ }^{85}$ The Âl Buwayh camp, which includes al-Shushtarī, claims as evidence statements made to that effect by 'Alī al-Karakī (al-Muhaqqiq al-Thānī, d. 940/1534) in his ijāzāt. ${ }^{86}$ In both cases, the evidence is weak. Overall, the question of al-Taḥtānìs descent veers toward the realm of legend and is far less significant than the question of whether he was actually a Shīì or Sunnì.

\section{Conclusion: What We Know about al-Taḥtānī}

Bearing all of this in mind, here is what we know about al-Tahtānī. ${ }^{87}$ His name, as it is most commonly attested, was Muhammad ibn Muhammad Quṭb al-Dīn al-Rāzì al-Tahtānī. Not until the tenth/sixteenth or early eleventh/seventeenth century do the nasabs Buwayhī and Ibn Bābawayh appear. In the cases of Buwayhī/Ibn Bābawayh and Abū Ja'far/Ibn Abī Ja'far, they only appear in Shīīi sources. All Sunnī scholars, starting with al-Asnawī, refered to Quṭb al-Dīn with his laqab, al-Taḥtānī.

As his nisba al-Rāzī suggests, al-Taḥtānī was from the city of Rayy. To be more precise, al-Shushtarī claims that he was from Warāmīn. ${ }^{88}$ While in Persia he mastered the rationalist disciplines (al-'aqliyyāt) and studied law. He studied under the Sunnī 'Adud al-Dīn al-Ijjī (d. 756/1356), something mentioned primarily in the Sunnī sources. ${ }^{89}$ This may have occurred at the Il-Khanid court of Abū Sa'îd (r. 71636/1316-36), who appointed al-İjī qãdì al-mamālik. ${ }^{90}$ He may also have studied in Cairo under Shams al-Dīn al-Aṣbahānī (d. 749/1349). Among his teachers is the Shî̀īal-Allāma al-Ḥillī (d. 726/1325), something mentioned only in Shī'î sources, ${ }^{91}$

al-Majlisī, Biḥār, 104:378.

al-Shushtarī, Majālis, 2:212. For the relevant part of the ijāza, see al-Majlisī, Bihăa r, 105:49.

In stating what we know about al-Taḥtānī, I prioritize the accounts written by his contemporaries and near contemporaries as well as all information that has multiple independent sources. I have less confidence in details that appear only in later sources or have only a single source. Some widely accepted details of his life, however - such as his being a student of al-Hilli - come only from much later sources. al-Shushtarī, Majālis, 2:212; Bosworth, "Warāmīn."

Ibn Qãdị Shuhba, Ṭabaqãt, 3:183. See the section above on Ibn Qādị Shuhba for the many later scholars who copied him in this regard. Al-Ișbahānī's Riyāḍ al-'ulamā' and al-Khwānsārī's Rawdẹat al-jannā (which is quoted by al-Ṭabarsī in his response to al-Khwānsārī) are the only bio-bibliographical sources composed by Shìîis that I found to mention that al-Tahtānī studied under the Sunnī al-İjī.

J. van Ess, "Al-İdjī," EI2, accessed June 6, 2019, http://dx.doi.org/10.1163/1573-3912_islam_ SIM_3486; al-Rahim, Philosophical Tradition, 132.

al-Shushtarī, Majālis, 2:212; al-Tafrishī, Naqd al-rijāl, 4:312; al-Ardabīlī, Jāmi‘', 2:187 (copying al-Tafrishī); al-'Āmilī, Amal al-āmil, 2:300; al-Majlisī, Bihạar, 105:377-78; al-Iṣbahānī, Riyāḍ, 5:168 (copying al-'Āmilī); al- 
which places him in a lineage of scholarly descendants of Nașīr al-Dīn al-Ṭūsì (d. 672/1274). Al-Ișbahānī (d. 1130/1718), citing an ijāza purportedly by Dawānī (d. 908/1502), claims that he was also a student of Quṭb al-Dīn al-Shīrāzī. ${ }^{92}$ This is unlikely to be true, as al-Rahim has recently argued. ${ }^{93}$ Starting with al-Shushtarī, Shi'î̀ sources commonly claim that al-Taḥtānī taught Muhammad ibn Makkīin'; others claim that he taught al-Sharīf al-Jurjānī (d. 816/1413) and Mubārakshāh. ${ }^{95}$

Quțb al-Dìn left Persia for Damascus, where he continued to pursue the rationalist disciplines. He arrived in 763/1361-62 ${ }^{96}$ and remained there, teaching and living at the Zāhiriyya madrasa, until his death. ${ }^{97}$ While in Damascus, he was a colleague of Taj al-Dìn al-Subkī. ${ }^{98}$

According to Ibn Kathīr, al-Taḥtānī was a leading scholar of the rationalist sciences, as well as a man of wealth who well-spoken and had poor eyesight. ${ }^{99} \mathrm{He}$ died on either 6 or 7 Dhu'l-Qa'dah 766/26 or 27 July 1365 in the outskirts of Damascus (zāhir Dimashq) ${ }^{100}$ and was allegedly buried at the foot of Mt. Qāsiyūn. ${ }^{101}$

What remains is the question of Quṭb al-Dīn's sectarian affiliation. Of the twenty-six sources I have examined, only six explicitly state that he was a Shāfi'í; one of those was written by a Shī'ī, while four were written by Shāfi'îs. The earliest one was by Abū Zur'a (d. 826/1423). That the sources contemporaneous (and nearly so) with al-Taḥtānī make no mention his sectarian affiliation suggests that this was not a question at that time. Nine sources claim that he was a Shīi î. All of these are by Shī'î scholars from the Safavī era or later; the earliest was by al-Shushtarī (d. 1019/1610), nearly 250 years after al-Taḥtānī's death. If al-Taḥtānī were a Shīî̀, one must ask why it took so long for any source to say so.

Baḥrānī, Lu'lu'at Bahrayn, 188 (copying al-Āmilī); al-Ḥā'irī, Muntahā l-maqāl, 6:175 (copying al-Tafrishī); al-Ṭabarsī, Khātimat, 2:passim.

92 al-Iṣbahānī, Riyā ḍ, 5:171.

93 al-Rahim, Philosophical Tradition, 22-23.

94 al-Shushtarī, Majālis, 2:213.

95 Ṭaşköprīzade, Miftāḥ al-sa'āda, 1:275; al-Ișbahānī, Riyāẹ, 5:170.

96 al-Subkī, Țabaqāt, 9:\#1334, 275.

97 Ibn Qāḍi Shuhba, Ṭabaqāt, 3:183; Ibn Ḥajar al-'Asqalānī, al-Durar al-kāmina, 4:339.

98 al-Subkī, Țabaqāt, 9:275.

99 Ibn Kathīr, as reported in Ibn Qāḍi Shuhba, Ṭabaqāt, 3:184; Ibn Ḥajar al-'Asqalānī, al-Durar al-kāmina, 4:339.

100 Ibn Rāfi' says the sixth. Ibn Rāfi', al-Wafayāt, 2:299. Al-Subkī says the sixth or sixteenth. Al-Subkī, Tabaqāt, 9:275. Abū Zur'a, who claims that Ibn Kathīr records his death date as the seventh, agrees with Ibn Rāfi but gives no explanation for doing so. Abū Zur'a, al-Dhayl, 185.

101 Ibn Rāfi', al-Wafayāt, 2:299; Abū Zư’a, al-Dhayl, 184; Ibn Kathīr via Ibn Qāḍi Shuhba, Ṭabaqāt, 3:184. Only Ibn Ṭūlūn suggests a different burial place. Ibn Țūlūn, al-Qalā’id, 1:341. 
Ahmed al-Rahim has recently offered an answer to this question. Arguing that alTaḥtānī was a Shāfi'î, he bases his conclusion on the strength of 1) al-Taḥtānī's having written a popular commentary on Qazwīnī's al-Ḥāwì al-șaghīr fí al-fatāwā, asking why a Shìîi would write a commentary on Shāfiì furü'; 2) what he calls the absurd notion that al-Taḥtānī could have been a Shìîi masquerading as a Shāfíî, although none of his Shāfíi biographers - even those who knew him, like al-Subkī - accused him of such $^{102}$; and 3) al-Taḥtānī's final resting place allegedly being among Sunnī scholars in the Khwārizmiyya mausoleum. Al-Rahim sees the effort by Shīî scholars to claim him as one of their own as an attempt to establish a chain of transmission among Shì'ī scholars from Nașīr al-Dīn al-Ṭūsī through Safavī-era scholars. ${ }^{103}$

Though persuasive, the upshot of al-Rahim's argument is that somewhere along the line, certain Shīìi scholars forged evidence of al-Taḥtānī's having been a Shīìi. How else are we to explain attestations to that effect in what purports to be al-Hilli's ijāza to al-Taḥtānī, Ibn Makkī's ijāzā to Ibn Khāzin, and Zayn al-Dīn ibn 'Alī's ijāza to al-Ḥusayn 'Abd al-Ṣamad? This seems as problematic as suggesting that al-Taḥtānī successfully dissimulated Shīîi beliefs for his entire life; both claims are hard to prove. Nevertheless, I agree with al-Rahim's conclusion. Al-Taḥtānī's having taught at the Zāhiriyya madrasa, the absence of any contemporaneous discussion of his sectarian affiliation, and the long gap between his death and the first claim that he was a Shi'i suggest that he was a Sunnī, or at least was believed to be so during his lifetime.

Regardless of his sectarian affiliation, however, he acted upon his clear affinity toward al-Ṭūsī and his brand of Avicennism in his commentary on Ibn Sīnā's alIshārāt. What is becoming increasingly clear as scholars pay more attention to the postclassical era of Arabic and Islamic scholarship is the significant role that al-Taḥtānī played, along with al-Hillī and al-Tustarī, in developing a narrative of Avicennism that promoted Nașīr al-Dīn al-Ṭūsī as its most celebrated exponent while simultaneously denigrating Avicenna's and Avicennism's Sunnī detractors. ${ }^{104}$

102 It is worth reiterating that al-Subkī made no explicit statement regarding al-Taḥtānī's sectarian affiliation.

103 al-Rahim, Philosophical Tradition, 35-36, 137-38.

104 On al-Taḥtānī's Muhākama and his role in developing a narrative of Avicennism that promoted al-Ṭūsī and denigrated Fakhr al-Dīn al-Rāzī, see Michael A. Rapoport, "The Life and Afterlife of the Rational Soul: Chapters VIII-X of Ibn Sīnā's Pointers and Reminders” (Ph.D. Dissertation, Yale University, 2018), chs. 6 and 7. It is worth noting that al-Rahim also argues that, like al-Taḥtānī, al-Tustarī was a Shāfìì. Al-Rahim, Philosophical Tradition, 127. 


\section{Bibliography}

Abū Zư'a, Ahmad ibn 'Abd al-Rahīm Ibn al-'Irāqī. Al-Dhayl 'alā l-íbar fỉ khabar man 'abar. Edited by Șālị̣ Mahdī 'Abbās. Beirut: Mu’assasat al-Risāla, 1989.

al-Āmilī, Muhamammad ibn al-Ḥasan al-Ḥurr. Amal al-ämil. Edited by Aḥmad Ḥusaynī. Qum: Dār al-Kitāb alIslāmī, n.d.

Amoretti, B. Scarcia. "Muhammad b. Makkī." In Encyclopaedia of Islam, Second Edition, edited by P. Bearman, Th. Bianquis, C. E. Bosworth, E. van Donzel, and W. P. Heinrichs. Brill. Accessed June 6, 2019. http:// dx.doi.org/10.1163/1573-3912_islam_SIM_5361.

al-Ardabīlī, Muhammad ibn 'Alī. Jāmi' al-ruwāt wa-izāhat al-ishtibāhāt 'an al-țuruq wa-l-asnād. Qum: Maktabat Āyat Allāh al-'Użmā al-Mar'ashī al-Najafī, 1403 AH.

al-Asnawī, 'Abd al-Rahịim ibn al-Ḥasan. Țabaqāt al-Shāfíiyya. Edited by Kamāl Yūsuf al-Ḥùt. Beirut: Dār alKutub al-'Tlmiyya, 1987.

al-Bahrānī, Yūsuf. Lu'lu'at al-Bahrayn fi al-ijāzāt wa-tarāim rijāl al-hadìth. Edited by Muḥammad Ṣadiq al-Baḥr al-'Ulūm. Manama: Maktabat Fakhrāwī, 2008.

al-Bihbahānī, Muhammad Bāqir. Ta'īqa 'alā Minhāj al-maqāl, n.d. http://shiaonlinelibrary.com/الكتب.

Bosworth, C. E. "Warāmīn." In Encyclopaedia of Islam, Second Edition, edited by P. Bearman, Th. Bianquis, C. E. Bosworth, E. van Donzel, and W. P. Heinrichs. Brill. Accessed May 24, 2019. http://dx.doi. org/10.1163/1573-3912_islam_COM_1338.

al-Bukhārī, Muhammad ibn Ismāîl. The Translation of the Meanings of Sahîh Al-Bukhâri: Arabic-English. Translated by Muhammad Muhsin Khan. Riyadh: Darussalam, 1997.

al-Dāwūdī, Shams al-Dīn Muhammad ibn ‘Alī. Țabaqāt al-mufassirinn. Edited by ‘Alī Muhammad 'Umar. Cairo: Maktabat Wahba, 1972.

Endress, Gerhard. "Reading Avicenna in the Madrasa. Intellectual Genealogies and Chains of Transmission of Philosophy and the Sciences in the Islamic East." In Arabic Theology, Arabic Philosophy. From the Many to the One: Essays in Celebration of Richard M. Frank, edited by James E. Montgomery, 371-422. Leuven: Peeters, 2006.

Ess, J. van. "Al-İdjī." In Encyclopaedia of Islam, Second Edition, edited by P. Bearman, Th. Bianquis, C. E. Bosworth, E. van Donzel, and W. P. Heinrichs. Brill. Accessed June 6, 2019. http://dx.doi.org/10.1163/15733912_islam_SIM_3486.

Ḥājjī Khalīfa, Mușțafā 'Abd Allāh al-Qusțanțīnī al-Kātib Çelebi. Kashf al-ẓunūn 'an asāmī l-kutub wa-l-funūn. Beirut: Dār al-Fikr, 1982.

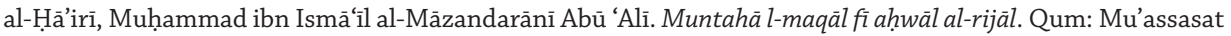
Āl al-Bayt, 1995.

Ibn al-'Imād, 'Abd al-Ḥayy ibn Aḥmad. Shadharät al-dhahab fi akhbär man dhahab. Cairo: Maktabat al-Qudsī, 1931. Shadharāt al-dhahab fi akhbär man dhahab. Beirut: Dār Ibn Kathīr, 1992.

Ibn Ḥajar al-'Asqalānī, Aḥmad ibn 'Alī. Al-Durar al-kāmina fí a'yān al-mi'a al-thāmina. Beirut: Dār al-Jîl, 1993.

Ibn Qāḍī Shuhba, Abū Bakr ibn Aḥmad. Ṭabaqāt al-Shāfíiyya. Edited by 'Abd al-'Alīm Khān. Ḥaydarābād alDakan: Mațba‘ Majlis Dā’irat al-Ma'ārif al-'Uthmāniyya, 1979.

Tārikkh Ibn Qādị Shuhba. Edited by 'Adnān Darwīsh. Damascus: al-Ma'had al-Faransī li-l-Dirāsāt al'Arabiyya, 1994.

Ibn Rāfi', Taqī l-Dīn Abū l-Ma‘āī Muhạmmad al-Sallāmī. Al-Wafayāt. Edited by Ṣaliḥ Mahdī 'Abbās and Bashshār 'Awwād Ma'rūf. Beirut: Mu’assasat al-Risāla, 1984.

Ibn Taghrỉbirdī, Abū l-Mahāsin Yūsuf. Al-Nujūm al-zāhira fì mulūk Miṣr wa-l-Qāhira. Cairo: al-Mu’assasa alMișriyya al-'Amma li-l-Ta'lif wa-l-Tarjama wa-l-Ṭibā‘a wa-l-Nashr, 1963.

Ibn Țūlūn, Shams al-Dīn Muhammad ibn 'Alī. Al-Qalä’id al-jawhariyya fì tārīkh al-Șālihhiyya. Edited by Muhammad Aḥmad Duhmān. Damascus: Majma' al-Lugha al-'Arabiyya, 1980. 
al-Iṣbahānī, 'Abd Allāh ibn 'Īsā. Riyāḍ al-'ulamā' wa-hiyāẹ al-fuḍalā'. Edited by Ahmad Husaynī. Qum: Maṭba'at al-Khayyām, 1980.

Kaḥhāla, 'Umar Riḍā. Mu'jam al-mu'allifin tarājim mușannifí l-kutub al-'arabiyya. Beirut: Mu'assasat al-Risāla, 1993.

al-Khwānsārī, Muḥammad Bāqir. Rawḍāt al-jannāt fì aḥwāl al-ulamā' wa-l-sādāt. Tehran: al-Maṭba'a alHaydariyya, $1390 \mathrm{AH}$.

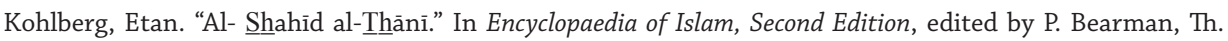
Bianquis, C. E. Bosworth, E. van Donzel, and W. P. Heinrichs. Brill. Accessed May 24, 2019. http:// dx.doi.org/10.1163/1573-3912_islam_SIM_6763.

al-Lajna al-'ilmiyya fī mu'assasat al-Imām al-Șādiq. Mawsū'at țabaqāt al-fuqahā’. Edited by Ja'far al-Subhānī. Qum: Maktabat al-Tawhīe, 1419 AH.

Madelung, W. "Al-Taftāzānī." In Encyclopaedia of Islam, Second Edition, edited by P. Bearman, Th. Bianquis, C. E. Bosworth, E. van Donzel, and W. P. Heinrichs. Brill. Accessed July 24, 2018. http://dx.doi. org/10.1163/1573-3912_islam_SIM_7296.

al-Majlisī, Muḥammad Bāqir. Biḥār al-anwār al-jāmía li-durar akhbār al-a'immma al-ațhār. Beirut: Mu'assasat al-A'lamī li-l-Mațbū'āt, 2008.

al-Maqrīzī, Taqī al-Dīn Aḥmad ibn 'Alī. Al-Sulūk li-ma'rifat duwal al-mulūk. Edited by Muhammad 'Abd alQādir 'Ațā. Beirut: Dār al-Kutub al-'Ilmiyya, 1997.

Rapoport, Michael A. "The Life and Afterlife of the Rational Soul: Chapters VIII-X of Ibn Sīnä’s Pointers and Reminders.” Ph.D. Dissertation, Yale University, 2018.

Al-Rahim, Ahmed H. The Creation of Philosophical Tradition: Biography and the Reception of Avicenna's Philosophy from the Eleventh to the Fourteenth Century A.D. Wiesbaden: Harrassowitz, 2018.

Salibi, K. S. "Abū Zur'a." In Encyclopaedia of Islam, Second Edition, edited by P. Bearman, Th. Bianquis, C. E. Bosworth, E. van Donzel, and W. P. Heinrichs. Brill. Accessed June 5, 2019. http://dx.doi. org/10.1163/1573-3912_islam_SIM_8279.

Schmidtke, Sabine. "Ḥelli, Hasan b. Yusof b. Moțahhar." In Encyclopaedia Iranica, 2012. http://www. iranicaonline.org/articles/helli-hasan-b-yusof-b-motahhar.

Shushtarī, Nūr Allāh ibn 'Abd Allāh. Kitāb-i Mustațāb-i Majālis al-mu’minīn. Tehran: Kitābfurūshī-yi Islāmiyya, 1995.

Street, Tony. "Kātibī (d. 1277), al-Tahtānī (d. 1365), and the Shamsiyya." In The Oxford Handbook of Islamic Philosophy, edited by Khaled El-Rouayheb and Sabine Schmidtke, 348-74. New York: Oxford University Press, 2016.

al-Subkī, Tāj al-Dīn 'Abd al-Wahhāb ibn 'Alī. Țabaqāt al-Shāfíiyya al-kubrā. Edited by 'Abd al-Fattāḥ Muḥammad al-Ḥilw and Maḥmūd Muḥammad Ṭanāḥī. Cairo: Dār Iḥyā’ al-Kutub al-'Arabiyya, 1964.

al-Suyūțī, 'Abd al-Raḥmān. Bughyat al-wu'āt fỉ țabaqāt al-lughawiyyīn wa-l-nuḥāt. Edited by Muhammad Abū al-Faḍl Ibrāhīm. Beirut: Dar al-Fikr, 1979.

al-Ṭabarsī, Husayn Taqī l-Nūrī. Khātimat Mustadrakal-wasā'il. Beirut: Mu'assasat Āl al-Bayt li-Ihyā’ al-Turāth, 2008.

al-Tafrishī, Mușțafā ibn al-Husayn. Naqd al-rijāl. Qum: Mu'assasat Āl al-Bayt li-Ihyā' al-Turāth, 1418 AH.

Ṭaşköprīzade, Aḥmad ibn Muṣțafā. Miftāḥ al-sa'āda wa-miṣbāḥ al-siyāda fì mawḍ̄'āt al-'ulūm. Beirut: Dār alKutub al-'Ilmiyya, 1985.

Wisnovsky, Robert. "Avicennism and Exegetical Practice in the Early Commentaries on the al-Ishārāt." Oriens 41, no. 3-4 (2013): 349-78.

“On the Emergence of Maragha Avicennism." Oriens 46, no. 3-4 (2018): 263-331.

“Towards a Genealogy of Avicennism." Oriens 42, no. 3-4 (2014): 323-63.

Ziriklī, Khayr al-Dīn. Al-A'tām: qāmūs tarājim li-ashhar al-rijāl wa-l-nisā' min al-'arab wa-l-musta'ribīn wa-lmustashriqīn. Beirut: Dār al-'Ilm li-l-Malāyīn, 2002. 